UDC 657.31.006.032

JEL Classification: M40, M41, M48

DOI: https://doi.org/10.32317/2221-1055.201906036

L.V. HUTSALENKO, doctor of economic sciences, professor

U.O. MARCHUK, candidate of economic sciences, associate professor (docent)

\title{
Financial statements according to the international financial reporting standards: requirements and realities of implementation
}

The purpose of the article is to study peculiarities of the information formation in financial statements in accordance with the requirements of international financial reporting standards (IFRS) and its importance for external users in a market environment.

Research methods. In the process of research were used general philosophical and general scientific methods of knowledge of phenomena and processes: abstract and logical for interpretation of an essence of financial reporting; comparison, analogy and systematization for assessing the legal provisions and prerequisites for the introduction of international standards of financial reporting; monographic method for analysis of evolution of scientific achievements of domestic scientists regarding problems of financial reporting by economic entities in accordance with the requirements of international standards; empirical method for comprehensive assessment of the current state of the research object; evolutionary approach and historical method for formation of implementation stages of the international standards of financial reporting in Ukraine.

Research results. In the process of studying issues regarding the formation of financial statements in accordance with the requirements of international standards, a number of prerequisites were introduced that preceded a need for financial statements to be prepared in accordance with the international standards. There were formed periods for implementation of IFRS in Ukraine, in particular: early period, transitional period, period of voluntary use, period of formation of institutional mechanism, and period of global euro integration processes.

Elements of scientific novelty. The theoretical positions concerning the implementation of the international financial reporting standards were further developed, the authors' vision of an essence of financial reporting as a socially important information tool for representing the financial and property status and results of business entities of the market economy were formed.

Practical significance. There were outlined approaches, which are expedient to use in two financial reporting systems (for SAS and IFRS), namely the method of transformation and the method of conversion. Tabl.: 3. Figs.: 4. Refs.: 20.

Keywords: system; accounting theories; financial reporting; international standards of financial reporting; principles; qualitative characteristics.

Hutsalenko Liubov Vasylivna - doctor of economic sciences, professor, professor of the accounting and taxation department, National University of Life and Environmental Sciences of Ukraine (11, Heroiv Oborony str., Kyiv)

E-mail: lyboffv@gmail.com

ORCID iD https://orcid.org/0000-0001-5181-8652

Marchuk Uliana Oleksandrivna - candidate of economic sciences, associate professor (docent), associate professor (docent) of the accounting and taxation department, Kyiv National Economic University named after Vadym Hetman (49/h, Dehtiarivska str., Kyiv)

E-mail: mar4ukuliana@gmail.com

ORCID iD https://orcid.org/0000-0003-0971-1303

Scientific problem. Financial reporting is an information product for users of the micro and macro environment and should provide them with high-quality and reliable information and influence the effectiveness of their decisions. It is precisely in the conditions of uncertainty and limited resources of economic entities

(c) L.V. Hutsalenko, U.O. Marchuk, 2019 financial reporting serves the most important source of modern information management system that provides management decisions.

Formation of financial statements based on uniform transparent principles, defined by the requirements of international standards of financial reporting, will allow its users to ensure the preservation of capital and the 
avoidance of risks of the negative effects of its investment.

Analysis of recent research and publications. The works of such scientists are devoted to the peculiarities of the implementation of the International Financial Reporting Standards and the Transformation of Financial Reporting in accordance with the requirements of domestic legislation: Bezverkhogo K.V., Zhuk V.M. [4, 5, 20], Legenchuk S.F., Luchka M.R. [7], Novodvorskaya V.V. [13], Pylypenko L.M. [14], Sydorenko R.V. [18], Smirnova O.V., Shevery Ya.V., Yatsunska O.S. [19] and others.

Without diminishing the importance of the research conducted by domestic scientists, there remain a number of problems that arise in the development of society and require research and new approaches.

The purpose of the article is to study the peculiarities of the formation of information in the financial statements in accordance with the requirements of international financial reporting standards (IFRS) and its importance for external users in a market environment.

Research results. In addition, financial statements as an economic category are present in many imperative norms, allocate (direct) profits, pay dividends, pay management fees, etc. Consequently, the reliability of the financial statements in terms of the efficiency of an enterprise depends on the objectivity of the distribution of social income, the investment attractiveness of a particular subject and the national economy as a whole [14, p.232].
It is worth noting that financial statements have been reflected for a long time, both in the legislative framework and in the researches of leading scientists. But at the same time, each scientist and normative act submit differently the definition of the category "financial statements".

Here are the results of theoretical studies of domestic scientists regarding the interpretation of the essence of "financial reporting" (Table 1).

The analysis of various interpretations shows that the semantics of the general definition of "financial reporting" is related to the terms "system", "methods, techniques, methods", "information resources", "economic indicators", which are subject to research and study.

Large-scale economic reforms have led to the formation of a new economic system and the development of market relations in Ukraine. The requirement of time is the development of foreign economic relations both at the state level and at the level of economic entities. The need for financial reporting under international standards is a set of prerequisites, in particular:

- increase of business entities engaged in international business;

- active exit of enterprises into international financial markets;

- attraction of foreign capital into the domestic economy;

- Ukraine's integration into the European economic space.

Table 1. Theoretical approaches to the interpretation of the essence of "financial statements"

\begin{tabular}{|c|c|c|c|c|c|c|c|c|c|c|c|}
\hline Approach & 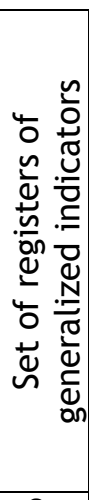 & 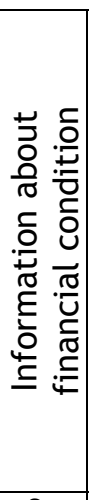 & 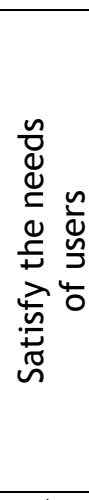 & 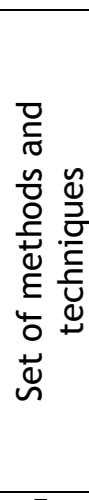 & 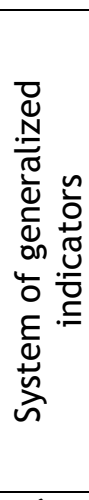 & 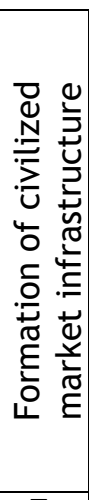 & 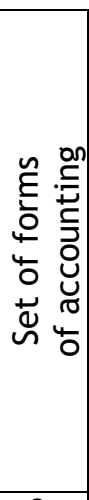 & 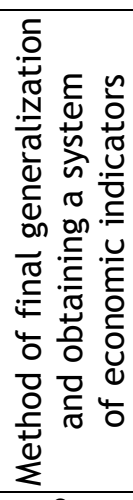 & 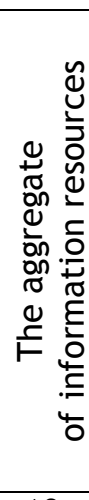 & 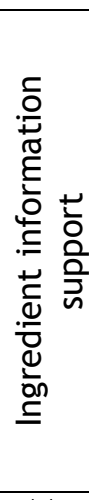 & 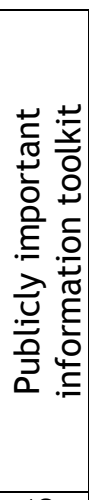 \\
\hline 1 & 2 & 3 & 4 & 5 & 6 & 7 & 8 & 9 & 10 & 11 & 12 \\
\hline $\begin{array}{l}\text { NAS } 1 \text { "General requirements } \\
\text { for financial Reporting" [11] }\end{array}$ & & + & & & & & & & & & \\
\hline $\begin{array}{l}\text { IAS } 1 \text { Presentation of Financial } \\
\text { Statements [9] }\end{array}$ & & & + & & & & & & & & \\
\hline $\begin{array}{l}\text { Law of Ukraine "On Accounting } \\
\text { and Financial Reporting in } \\
\text { Ukraine" [15] }\end{array}$ & & + & & & & & & & & & \\
\hline
\end{tabular}


Continued table 1

\begin{tabular}{|l|l|l|l|l|l|l|l|l|l|l|l|}
\hline $\begin{array}{l}\text { Bakurova G.V., Trohymets O.I. } \\
{[1]}\end{array}$ & & & & + & & & & & & & \\
\hline Veriga Yu. A. [2] & & & & & + & & & & & & \\
\hline Davidenko N.M. [3] & & & & & & + & & & & & \\
\hline Kiiretsev G.G. [6, p.165] & & & & & & & + & & & & \\
\hline $\begin{array}{l}\text { Luchko M.R., Benko I.D. } \\
\text { [, p.355] }\end{array}$ & & + & & & & & & & & & \\
\hline $\begin{array}{l}\text { Mysaka G.V., Sharmanska V.M. } \\
\text { [8, p. 21] }\end{array}$ & & & & + & & & + & & & \\
\hline $\begin{array}{l}\text { Neopochatenko 0.O. } \\
{[12, \text { p.165] }}\end{array}$ & & & & & & & & & & + & \\
\hline Pushkar M.S. [13, p.296-334] & + & & & & & & & & & & \\
\hline Shevera Ya.V. [19] & & & & & & & & & + & & \\
\hline Zhuk V.M.[4, 5, 20] & & & + & & & & & & & + & + \\
\hline $\begin{array}{l}\text { Author's vision } \\
\text { Number of common features }\end{array}$ & 1 & 3 & 1 & 1 & 2 & 1 & 1 & 1 & 1 & 1 & 1 \\
\hline
\end{tabular}

Source: Summarized by authors.

Investigating the evolution of financial reporting by business entities in Ukraine in

accordance with the requirements of IFRS, several stages were identified (Table 2).

Table 2. Stages of Implementation of International Financial Reporting Standards in Ukraine

\begin{tabular}{|l|c|l|}
\hline \multicolumn{1}{|c|}{ Stage } & Period & \multicolumn{1}{c|}{ Characteristics } \\
\hline Early period & 2 & \multicolumn{1}{c|}{ 3 } \\
\hline Transition period & $2002-2005$ & $\begin{array}{l}\text { Legislative decision was made regarding permission to use } \\
\text { IFRS by business entities. }\end{array}$ \\
\hline $\begin{array}{l}\text { The period } \\
\text { of voluntary use }\end{array}$ & $2012-2014$ & $\begin{array}{l}\text { Creation of economic and political requirements } \\
\text { for obligatory application of IFRS by listed companies } \\
\text { in pursuance of the decision of the European Union in } \\
\text { accordance with Decree № 1606/2002. }\end{array}$ \\
\hline $\begin{array}{l}\text { Period of formation } \\
\text { of the institutional } \\
\text { mechanism }\end{array}$ & $\begin{array}{l}\text { The process of introducing IFRS by business entities has } \\
\text { become widespread. }\end{array}$ \\
\hline $\begin{array}{l}\text { The period of global } \\
\text { eurointegration } \\
\text { processes }\end{array}$ & $2015-2017$ & $\begin{array}{l}\text { Transition to the formation of financial statements under } \\
\text { IFRS by the banking system of Ukraine. } \\
\text { Gradual decrease in the number of economic entities that } \\
\text { formed financial statements under IFRS due to the economic } \\
\text { crisis and political events. }\end{array}$ \\
\hline
\end{tabular}

Source: Formed by authors.

It is worth mentioning that the transition period to the international standards of financial reporting in Ukraine has a long term.

At the current stage of international integration in the field of economy and management, one can distinguish such an important tendency of accounting and financial reporting development as convergence, harmonization, unification of rules and accounting procedures, requirements for financial statements, accounting standards and financial statements of economic entities at the level EU countries, convergence of economic, accounting and financial legislation of Ukraine taking into account the requirements of international standards and legislation of the European Union [18, p.128-131].

According to V.M. Zhuk, academic science recommends that the Ministry of Finance of Ukraine not implement, but adapt to the institutional conditions of Ukraine, international financial reporting provisions. Such adaptation should be carried out for additional compliance with a number of key principles: 1) from simple to complex; 2) historical heredity; 3 ) the priority of standardization; 4) generalization [4, p. 24].

In today's economic conditions, financial statements of economic entities of Ukraine are regulated in accordance with the National Accounting Standard (Standard) 1 "General Requirements for Financial Statements" and has the following composition (Table 3). 
Table 3. Characteristics of the financial statements of the specified NAS and IFRS

\begin{tabular}{|l|l|}
\hline \multicolumn{1}{|c|}{ Report title } & \multicolumn{1}{c|}{ Characteristic } \\
\hline \multicolumn{1}{|c|}{\begin{tabular}{l}
\multicolumn{1}{|c|}{ Balance sheet } \\
(Statement of Financial \\
Position)
\end{tabular}} & $\begin{array}{l}\text { The assets, liabilities and equity of economic entities are displayed. Comes } \\
\text { to the end of the last day of the reporting period. }\end{array}$ \\
\hline $\begin{array}{l}\text { Financial Statement } \\
\text { (Consolidated Income } \\
\text { Statement) }\end{array}$ & $\begin{array}{l}\text { Discloses information on income, expenses, profits and losses, other } \\
\text { comprehensive income and total income of enterprises during the reporting } \\
\text { period. }\end{array}$ \\
\hline Statement of Cash Flows & $\begin{array}{l}\text { The data on cash flow during the reporting period as a result of operational, } \\
\text { investment and financial activity is presented. }\end{array}$ \\
\hline $\begin{array}{l}\text { Statement of Equity } \\
\text { (Statement of Changes } \\
\text { in Equity) }\end{array}$ & $\begin{array}{l}\text { Information about changes in the equity of the enterprise during } \\
\text { the reporting period is disclosed. }\end{array}$ \\
\hline $\begin{array}{l}\text { Notes to the financial } \\
\text { statements }\end{array}$ & $\begin{array}{l}\text { Information about the purpose and conditions for using each element } \\
\text { of equity (except for registered capital) is given. }\end{array}$ \\
\hline
\end{tabular}

Source: Summarized by authors on a basis [13].

It is worthwhile to emphasize the fact that with the adoption of the National Accounting Standards (Standard) 1 "General Requirements for Financial Statements" and the formulation of financial statements, the revival of scientific polemics on the implementation of IFRS in Ukraine has been encouraged.

When designing financial statements, it must be remembered that each component of the financial statements has its own purpose and each component needs a clear identification.

No less important is the definition of requirements that it must meet. In today's conditions of the development of market relations in Ukraine, the regulation of the formation of information in financial reporting is carried out by means of the use of normative documents, which are divided into three levels (Figure 1), this is facilitated by the use of the legislative framework of Ukraine, as well as advanced world experience.

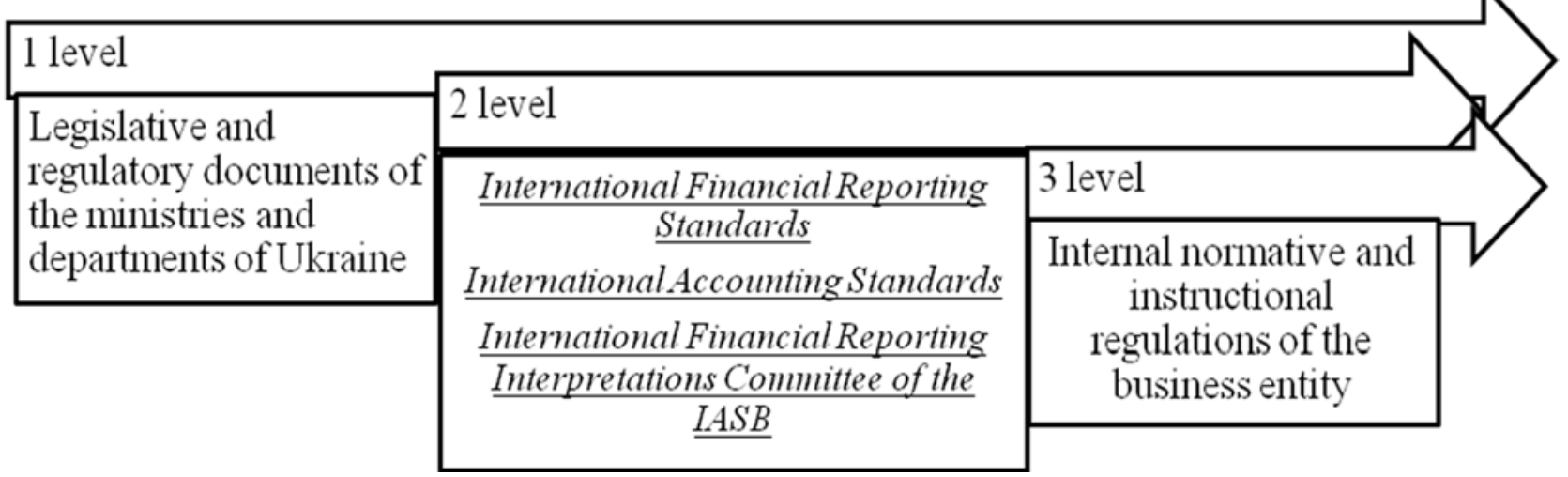

Figure 1. Levels of normative documents that regulate the procedure for the formation of financial statements of enterprises

Source: Formed by the authors.

In accordance with the Law of Ukraine "On Amendments to the Law of Ukraine" On Accounting and Financial Reporting in Ukraine "regarding the improvement of certain provisions dated $10 / 5 / 2017$, the financial statements of an enterprise are formed in compliance with the following principles (Figure 2).

International financial reporting standards foresee the division of financial reporting principles into two groups:
1) the main assumptions of financial statements, which are ensured by observance of the principles of accrual and continuity of activities;

2) qualitative characteristics of financial reporting, which are provided by principles clearness, comparability, relevance (materiality, timeliness), reliability (completeness, neutrality, prudence, prevalence of the essence over the form). 


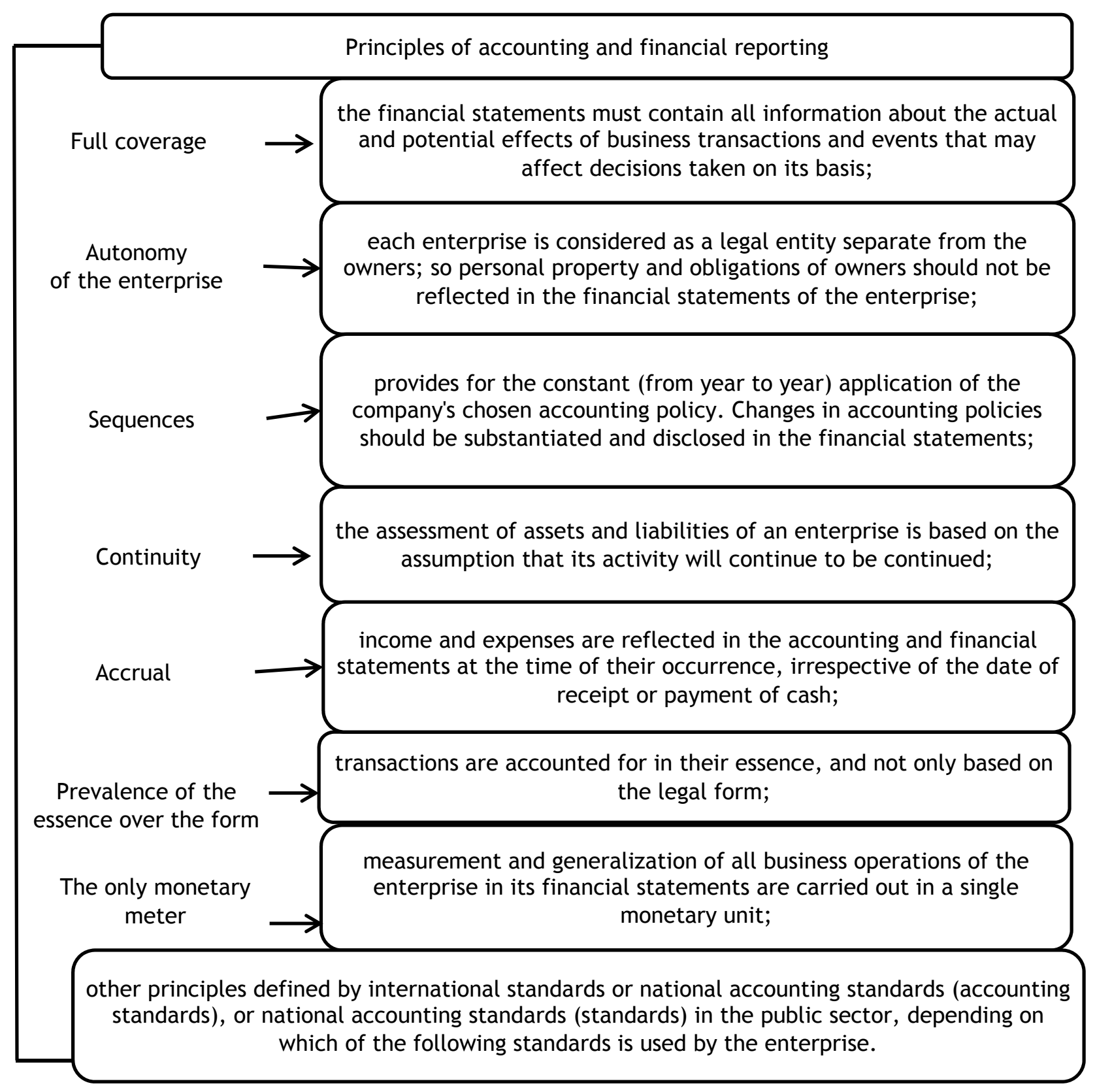

Figure 2. Principles on which the presentation of financial statements is based

Source: Summarized by authors on a basis [16].

The main objective of the legislative changes is to bring Ukrainian legislation in line with the legislation of the European Union and to update the procedure for the application of International Financial Reporting Standards (IFRS). The Committee on International Financial Reporting Standards is guided by the general principles of their preparation when drafting IFRS, the goals which the Committee seeks to achieve when developing and approving IFRS.

The principles disclose the general approaches of the IFRS Committee to international financial reporting standards, assist compilers and users of financial statements, and auditors to interpret the individual IFRSs correctly and reflect transactions that are not yet covered by standardization. Internal normative and instructional regulations of the business entity determine the accounting policy of economic entities, which contributes to the formation of their strategic development and effective management decision-making.

The International Financial Reporting Standards have the mandatory composition of the financial statements, in particular: the statement of financial position at the end of the period; A statement of comprehensive income for the period (information on components of profit and loss, presented either as part of this report, or as a separate statement of comprehensive income before the state- 
ment of comprehensive income); Statement of changes in equity for the period; Cash flow statement for the period; notes that contain a summary of accounting policies and other explanations. The notes are the most significant and integral part of the IFRS statement. Formation of financial statements in accordance with the requirements of international standards promotes the harmonization of accounting and reporting globally.
The analysis of the requirements that need to be put in the financial statements is carried out by many scholars. Thus, V.G. Shvets, analyzing the system of requirements for financial reporting, divides them into legal aspects and qualitative characteristics. Legal aspects of financial reporting are shown in Figure 3.

Regarding qualitative characteristics, according to the research VG Swedes are the following (Figure 4).

Obligatory submission - enterprises are obliged to report to the authorities to which they belong, to owners, bodies of state executive power and other users;

Responsibility for certification - financial statements are formed on the basis of accounting data, for which the responsibility of the chief and chief accountant of the enterprise are responsible. This circumstance requires the certification of financial statements data signed by the head and chief accountant.

State regulation-taking into account the need to generalize the reporting indicators of enterprises of various types of economic activity, state bodies establish uniform rules and forms of compilation and indicators of financial reporting;

Figure 3. Legal aspects of financial reporting

Source: Generalized by authors R.V. Sidorenko [18, p. 129].

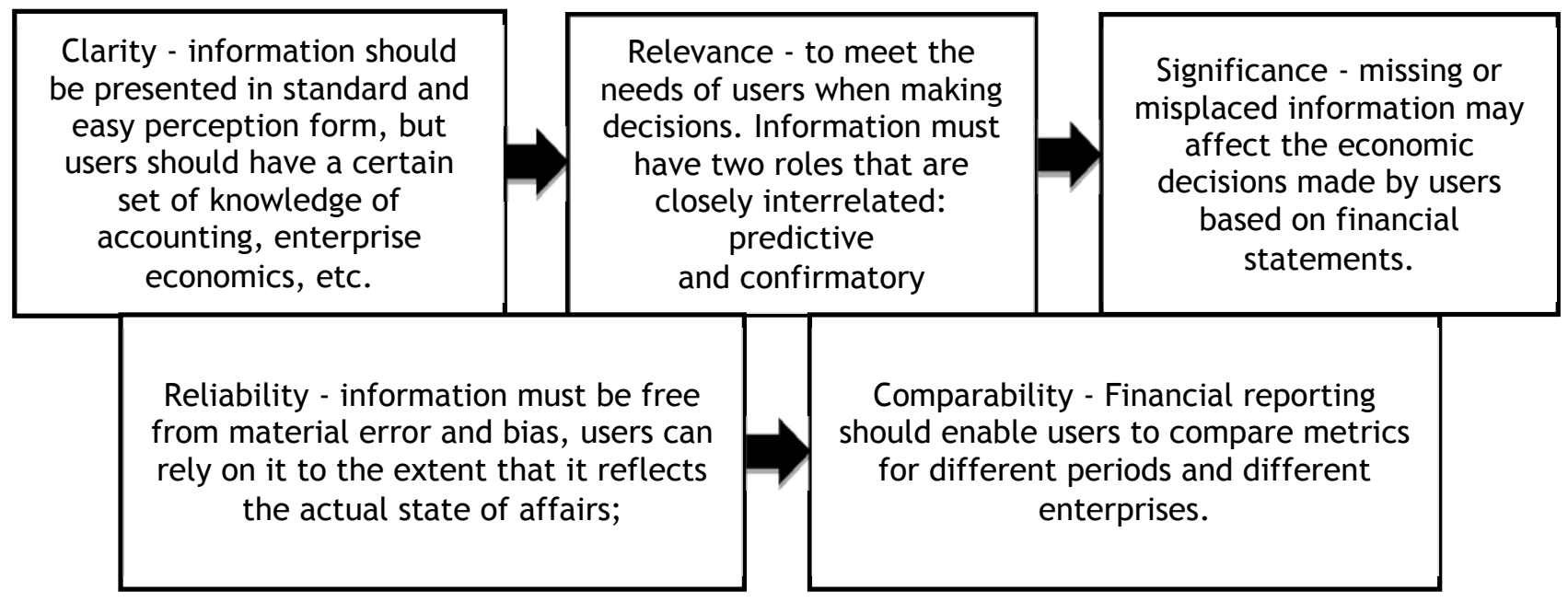

Figure 4. Qualitative characteristics of financial reporting

Source: Formed by the authors on the basis of research R.V. Sidorenko [18, p.129-130].

O.V. Levitskaya stresses that the reporting procedures, their forms, the list of indicators included in them are among the most varied elements of modern Ukrainian accounting.

Levina's share of the entities applying IFRS falls within the voluntary use period (voluntary IFRS adoption), namely, in 2012, their share is $90.49 \%$, in $2013-91.66 \%$, and in 2014 p $91.91 \%$ [19, p.180].

Thus, according to the Law on Amendments to the Law of Ukraine "On Accounting and Financial Reporting in Ukraine" regarding the improvement of some provisions, which entered into force on January 1, 2018, large enterprises that are not issuers of securities, and medium-sized enterprises are obliged not to later than by 1 June of the year following the reporting period, must publish the annual financial statements, together with the audit report, on its website (in full).

The first reporting period for which companies that are required to apply international standards file financial statements based on 
taxonomy in accordance with international standards in electronic form is 2019.

Based on this, it's worth knowing that the taxonomy of financial statements is the composition of the articles and indicators of financial reporting and its elements that are subject to disclosure. The taxonomy of financial statements is approved by the central executive body, which ensures the formation and implementation of the state policy in the field of accounting [16].

In accordance with IFRS 1, "First-time Adoption of International Financial Reporting Standards", two approaches to transition to IFRS are singled out: retrospective (preparation of the first financial statements for past periods) and forward-looking (focused on planning and preparing IFRS financial statements for future periods).

Ukrainian business entities use other approaches, in particular:

- parallel accounting (conversion) - the formation and display of business operations in two systems of financial reporting - for NSA and IFRS;

- the method of transformation - uses the report generated by NSA and analytical decoding to it on the articles of the Report on the financial position and the Report on financial results.

The purpose of IFRS 1, "First-time Adoption of International Financial Reporting Standards", is to provide the first financial statements of business entities compiled according to IFRS with high-quality information that is:

1) transparent to users and contained comparison elements in all displayed periods;

2) provides an acceptable starting point for accounting in accordance with International Financial Reporting Standards (IFRS);

\section{Список бібліографічних посилань}

1. Бакурова Г. В., Трохимець О. І. Значення фінансової звітності підприємств для прийняття рішень на ії основі. Держава та регіони. Сер. Економіка та підприємництво. 2013. - № 1. - C. 92-95. -URL: http://nbuv.gov.ua/UJRN/ drep_2013_1_20 (дата звернення: 03.03.2019).

2. Бухгалтерський облік i аудит: термінологічний українсько-російсько-англійський словник : навч. посіб. / Ю. А. Верига, В. Л. Іщенко, Т. В. Гладких, А. Ж. Пшенична, И. О. Кулявець. Київ : Центр учбової літератури, 2012. 292 с.

3. Давиденко Н. М. Фінансовий менеджмент : підручник Київ : ТОВ «Задруга», 2012. 516 с.

4. Жук В. М. Інтегрована звітність: ретроспектива і перспектива в Україні. Облік і фінанси. 2019. № 1(83). С. 20-27. DOI: https://doi.org/10.33146/2307-9878-2019-1(83)-20-27.

5. Жук В. М. Розвиток теорії бухгалтерського обліку: інституціональний аспект : монографія. Київ : ННЦ «ІАЕ», 2018. 408 c.

6. Кірейцев Г.Г. Фінансовий менеджмент. Житомир: ЖITI, 2001. 440 c.
3) requires additional efforts that do not exceed the benefits for users [10].

The entity is required to make adjustments related to the difference in IFRS from the previous accounting policies, with their reflection in the input retained earnings (or other relevant capital accounts).

The use of international financial reporting standards will: reduce risks for lenders and investors; deepening of international cooperation in the field of accounting; unambiguous understanding of financial reporting and the growth of international confidence in its performance.

Summarizing the foregoing, it can be argued that International Financial Reporting Standards (IFRS) cover a range of issues of international importance in the context of the development of foreign trade, the activities of transnational corporations, the globalization of financial markets. They play a significant role in improving the national accounting standards and integration of the state into the world community.

Conclusions. The 18th century, as well as modern scientific developments and normative-legislative acts. The identified essence, the main components, principles, legal aspects and qualitative characteristics of the reporting, allow us to interpret financial reporting as a socially important information tool for representing the financial and property status and the result of the business entities of the market economy.

The stages of the introduction of the IFRS and the peculiarities of the formation of financial statements of economic entities according to the requirements of the international standards of financial reporting and certain difficulties that arise at the stage of formation of such reporting for the first time are determined.

\section{References}

1. Bakurova, H.V. \& Trokhymets, O.I. (2013). Znachennia finansovoi zvitnosti pidpryiemstv dlia pryiniattia rishen na yii osnovi [Value of financial statements of enterprises for decision making on its basis]. Derzhava ta rehiony. Ser. Ekonomika ta pidpryiemnytstvo, 1, pp. 92-95. Retrieved from: http://nbuv.gov.ua/UJRN/drep_2013_1_20 [In Ukrainian].

2. Veriyha, Yu.A., Ishchenko, V.L., Hladkykh, T.V., Pshenychna, A.Zh., \& Kuliavets, Y.O. (2012). Bukhhalterskyi oblik $i$ audyt: terminolohichnyi ukrainsko-rosiisko-anhliiskyi slovnyk [Accounting and audit: terminological Ukrainian-Russian-English dictionary]. Kyiv: Tsentr uchbovoi literatury [In Ukrainian].

3. Davydenko, N.M. (2012). Finansovyi menedzhment: navchalnyi pidruchnyk. [Financial management: textbook]. Kyiv: TOV "Zaduha" [In Ukrainian].

4. Zhuk, V.M. (2019). Intehrovana zvitnist: retrospektyva i perspektyva $\vee$ Ukraini [Integrated reporting: retrospective and prospect in Ukraine]. Oblik $i$ finansy, 1 (83), pp. 20-27. DOI: https://doi.org/10.33146/2307-9878-2019-1(83)-20-27 [In Ukrainian]. 
7. Лучко М. Р., Бенько І. Д. Облік і фінансова звітність за міжнародними стандартами. Тернопіль : Екон. думка/ THEY, 2016. $360 \mathrm{c}$.

8. Мисака Г. В., Шарманська В. М. Бухгалтерський облік : навч. посіб. Київ : Центр учбової літератури, 2007. 400 с.

9. Міжнародний стандарт бухгалтерського обліку 1 (МСБО 1) «Подання фінансової звітності». Виданий Радою 3 Міжнародних стандартів бухгалтерського обліку зі змінами станом на 1 січня 2012 року. URL : http://zakon2.rada.gov.ua/ laws/show/929_013 (Дата звернення: 07.03.2019).

10. МСФЗ 1 «Перше застосування Міжнародних стандартів фінансової звітності». URL : www.minfin.gov.ua/ uploads/redactor/files/ifrs1.pdf (Дата звернення: 06.03.2019).

11. Національне положення (стандарт) бухгалтерського обліку 1 «Загальні вимоги до фінансової звітності». Затверджено наказом Міністерства фінансів України від 07.02.13 р. № 73 (зі змінами та допов.). URL : http://zakon3.rada.gov.ua/ laws/show/z0336-13 (дата звернення: 07.03.2019).

12. Непочатенко О. О., Мельничук Н. Ю. Фінанси підприємств : навч. підруч. Київ : «Центр учбової літератури", 2013. 504 c.

13. Новодворська В., Бондарєва О. Фінансова звітність та ii адаптація до міжнародних стандартів, 2015. URL : http://sophus.at.ua/publ/2015_03_27/ (Last accessed: 18.03.2019).

14. Пилипенко Л. М. Фінансова звітність: відповідність сучасним інформаційним потребам управління та регулювання ринковою економікою. Вісник Національного університету „Львівська політехніка” „Менеджмент та підприємництво в Україні: етапи становлення і проблеми розвитку”. 2011. № 720. С. 230-233.

15. Про бухгалтерський облік і фінансову звітність в Україні : Закон України від 16.07.1999 № 996-XIV (зі змінами та доповненнями). URL : http://zakon2.rada.gov.ua/laws/ sho-w/ 996-14 (Дата звернення: 16.03.2019).

16. Про внесення змін до Закону України «Про бухгалтерський облік та фінансову звітність в Україні» щодо удосконалення деяких положень : Закон України від 5.10.2017. № 44. URL : http://zakon2.rada.gov.ua/laws/show/2164-19.

17. Резнікова В. В., Орлова О. С. Перспективи гармонізації бухгалтерського обліку та фінансової звітності в Україні. Адміністративне право і процес. 2015. С. 296-334.

18. Сидоренко Р. В. Вимоги до фінансової звітності в сучасних умовах господарювання. Збірник наукових праць «Наукові записки Національного університету «Острозька академія». Сер. Економіка / ред. кол. : І. Д. Пасічник, О. І. Дем'янчук. Острог : Вид-во Нац. ун-ту «Острозька академія». 2013. Вип. 24. С. 128-131.

19. Яцунська О. С. Процес упровадження МСФЗ в Україні. Бізнесінформ. 2016. № 3. С. 173-182.

20. Zhuk V., Bezdushna Yu., Tyvonchuk S. Improvement of IFRS application policy in relation to land assets of agricultural enterprises. Independent Journal of Management \& Production. Special Edition PDATU-2019, May-2019. 2019. Vol. 10, No 7. Pp. 702-724. DOI: http://dx.doi.org/10.14807/ijmp.v10i7.889.
5. Zhuk, V.M. (2018). Rozvytok teorii bukhhalterskoho obliku: instytutsionalnyi aspekt: monohrafiia [Development of the theory of accounting: the institutional aspect: monograph]. Kyiv: NTC "IAE" [In Ukrainian].

6. Kireitsev, H.H. (2001). Finansovyi menedzhment [Financial management]. Zhytomyr: ZhITI [In Ukrainian].

7. Luchko, M.R. \& Benko, I.D. (2016). Oblik i finansova zvitnist za mizhnarodnymy standartamy [Accounting and financial reporting according to international standards]. Ternopil: Ekon. dumka TNEU [In Ukrainian].

8. Mysaka, H.V. \& Sharmanska, V.M. (2007). Bukhhalterskyi oblik: navch. pos. [Accounting: textbook]. Kyiv: Tsentr uchbovoi literatury [In Ukrainian].

9. Mizhnarodnyi standart bukhhalterskoho obliku 1 (MSBO 1) "Podannia finansovoi zvitnosti" [International accounting standard 1 (IAS 1) "Presentation of financial statements"]. (2012). Zakonrada. Retrieved from: http://zakon2.rada.gov.ua/ laws/show/929_013 [In Ukrainian].

10. MSFZ 1 "Pershe zastosuvannia Mizhnarodnykh standartiv finansovoi zvitnosti" [IFRS 1 "First-time adoption of International financial reporting standards"]. Minfin. Retrieved from: www.minfin.gov.ua/uploads/redactor/files/ifrs1.pdf [In Ukrainian].

11. Natsionalne polozhennia (standart) bukhhalterskoho obliku 1 "Zahalni vymohy do finansovoi zvitnosti" [National accounting standard (standard) 1 "General requirements for financial statements"]. (2013). Retrieved from: http://zakon3.rada.gov.ua/laws/ show /z0336-13 [In Ukrainian].

12. Nepochatenko, O.O. \& Melnychuk, N.Yu. (2013). Finansy pidpryiemstv: navchalnyi pidruchnyk [Finance companies: training manual]. Kyiv: Tsentr uchbovoi literatury [In Ukrainian].

13. Novodvorska, V. \& Bondareva, O. (2015). Finansova zvitnist ta yii adaptatsiia do mizhnarodnykh standartiv [Financial reporting and its adaptation to international standards]. Retrieved from: http://sophus.at.ua/publ/2015_03_27/ [In Ukrainian].

14. Pylypenko, L.M. (2011). Finansova zvitnist:vidpovidnist suchasnym informatsiinym potrebam upravlinnia ta rehuliuvannia rynkovoiu ekonomikoiu [Financial reporting: compliance with modern information needs of management and market economy regulation]. Visnyk Natsionalnoho universytetu „Lvivska politekhnika” „Menedzhment ta pidpryiemnytstvo $v$ Ukraini: etapy stanovlennia i problemy rozvytku, 720, pp. 230233 [In Ukrainian].

15. Pro bukhhalterskyi oblik i finansovu zvitnist v Ukraini: Zakon Ukrainy vid 16.07.1999 № 996-XIV [On accounting and financial reporting in Ukraine: Law of Ukraine No. 996-XIV dated 16.07.1999]. Retrieved from: http://zakon2.rada.gov.ua/ laws/sho-w/996-14 [In Ukrainian].

16. Pro vnesennia zmin do Zakonu Ukrainy Pro bukhhalterskyi oblik ta finansovu zvitnist $v$ Ukraini: Zakon Ukrainy vid 5.10.2017 № 44 [On amending the Law of Ukraine On accounting and financial reporting in Ukraine on improvement of certain provisions of the Law of Ukraine No. 44 dated 10.05.2017]. Retrieved from: http://zakon2.rada.gov.ua/laws/show/2164-19 [In Ukrainian].

17. Reznikova, V.V. \& Orlova, O.S. (2015). Perspektyvy harmonizatsii bukhhalterskoho obliku ta finansovoi zvitnosti $v$ Ukraini [Prospects for harmonization of accounting and financial reporting in Ukraine]. Administratyvne pravo i protses, pp. 296-334 [In Ukrainian].

18. Sydorenko, R.V. (2013). Vymohy do finansovoi zvitnosti v suchasnykh umovakh hospodariuvannia [Requirements for financial reporting in modern economic conditions]. Naukovi zapysky Natsionalnoho universytetu "Ostrozka akademiia". Seriia "Ekonomika": zbirnyk naukovykh prats, 24, pp. 128-131 [In Ukrainian].

19. Yatsunska, O.S. (2016). Protses uprovadzhennia MSFZ v Ukraini [The process of implementing IFRS in Ukraine]. Biznesinform, 3, pp. 173-182 [In Ukrainian].

20. Zhuk, V., Bezdushna, Yu., \& Tyvonchuk, S. (2019). Improvement of IFRS application policy in relation to land assets of agricultural enterprises. Independent Journal of Management \& Production. Special Edition PDATU-2019, May-2019, Vol. 10, No. 7. pp. 702-724. DOI: http://dx.doi.org/10.14807/ ijmp.v10i7.889. [In English].

Гуцаленко Л.В., Марчук У.О. Фінансова звітність за міжнародними стандартами фінансової звітності: вимоги та реалії впровадження

Мета статmі - дослідити особливості формування інформації у фінансовій звітності відповідно до вимог міжнародних стандартів фінансової звітності (МСФЗ) та їі вагомість для зовнішніх користувачів в умовах ринкового середовища. 
Методика дослідження. У процесі дослідження використано загальнофілософські та загальнонаукові методи пізнання явищ і процесів: абстрактно-логічний (при тлумаченні сутності фінансової звітності); порівняння, аналогії та систематизації (при оцінці законодавчих положень і передумов впровадження міжнародних стандартів фінансової звітності); монографічний (аналіз еволюції наукових здобутків вітчизняних учених щодо проблем формування фінансової звітності господарюючими суб'єктами відповідно до вимог міжнародних стандартів), емпіричний (щодо комплексної оцінки сучасного стану об'єкта дослідження); еволюційний підхід та історичний метод (при формуванні етапів впровадження міжнародних стандартів фінансової звітності в Україні).

Результати дослідження. У процесі вивчення питань щодо формування фінансової звітності відповідно до вимог міжнародних стандартів вказано на низку передумов, що передувала необхідності формування фінансової звітності за міжнародними стандартами. Визначено періоди впровадження МСФЗ в Україні, зокрема: ранній, перехідний, добровільного використання, формування інституціонального механізму, глобальних євроінтеграційних процесів.

Елементи наукової новизни. Набули подальшого розвитку теоретичні положення щодо впровадження міжнародних стандартів фінансової звітності, сформовано авторське бачення сутності фінансової звітності як суспільно важливого інформаційного інструментарію репрезентації фінансово-майнового стану $i$ результату діяльності господарюючих суб'єктів ринкової економіки.

Практична значущість. Виокремлено підходи, що доцільно використовувати у двох системах фінансової звітності (за П(С)БО і МСФЗ) - методи трансформації та конверції. Табл.: 3. Рис.: 4. Бібліогр.: 20.

Ключові слова: система; бухгалтерські теорії; фінансова звітність; міжнародні стандарти фінансової звітностіі; принципи; якісні характеристики.

Гуцаленко Любов Василівна - доктор економічних наук, професор, професор кафедри обліку та оподаткування, Національний університет біоресурсів і природокористування України (м. Київ, вул. Героїв Оборони, 11)

E-mail: lyboffv@gmail.com

ORCID: https: / / orcid.org/0000-0001-5181-8652

Марчук Ульяна Олександрівна - кандидат економічних наук, доцент, доцент кафедри обліку і оподаткування, Державний вищий навчальний заклад «Київський національний економічний університет імені Вадима Гетьмана» (м. Київ, вул. Дегтярівська, 49/г)

E-mail: mar4ukuliana@gmail.com

ORCID: http://orcid.org/0000-0003-0971-1303

Гуцаленко Л.В., Марчук У.А. Финансовая отчётность по международным стандартам финансовой отчётности: требования и реалии внедрения

Цель статьи - исследовать особенности формирования информации финансовой отчётности в соответствии с требованиями международных стандартов финансовой отчётности (МСФО) и её весомость для внешних пользователей в условиях рыночной среды.

Методика исследования. В процессе исследования использованы общефилософские и общенаучные методы познания явлений и процессов: абстрактно-логический (при толковании сущности финансовой отчетности); сравнения, аналогии и систематизации (при оценке законодательных положений и предпосылок внедрения международных стандартов финансовой отчётности); монографический (анализ эволюции научных дострижений отечественных ученых в изучении проблем формирования финансовой отчетности хозяйствующими субъектами относительно требований международных стандартов) эмпирический (относительно комплексной оценки современного состояния объекта исследования), эволюционный подход и исторический метод (при формировании этапов внедрения международных стандартов финансовой отчетности в Украине).

Результаты исследования. В процессе изучения вопросов формирования финансовой отчётности в соответствии с требованиями международных стандартов указано на ряд предпосылок, предшествующих необходимости формирования финансовой отчетности по международным стандартам. Определены периоды внедрения мСФЗ в Украине, в частности: ранний, переходный, добровольного использования, формирования инстуционального механизма, глобальных евроинтеграционных процессов.

Элементы научной новизны. Получили дальнейшее развитие теоретические положения относительно внедрения международных стандартов финансовой отчетности, сформировано авторское видение сущности финансовой отчетности как общественно важного информационного инструментария репрезентации финансово-имущественного состояния и результата деятельности хозяйствующих субъектов рыночной экономики.

Практическая значимость. Определены подходы, которые челесообразно использовать в двух системах финансовой отчетности (по П(С)БО и МСФО) - методы трансформации и конверции. Табл.: 3. Илл.: 4. Библиогр.: 20.

Ключевые слова: система; бухгалтерские теории; финансовая отчётность; международные стандарты финансовой отчётности; принципы; качественные характеристики.

Гуцаленко Любовь Васильевна - доктор экономических наук, профессор, профессор кафедры учёта и налогообложения, Национальный университет биоресурсов и природопользования Украины (г. Киев, ул. Героев Обороны, 11)

E-mail: lyboffv@gmail.com

ORCID: https://orcid.org/0000-0001-5181-8652

Марчук Ульяна Александровна - кандидат экономических наук, доцент, доцент кафедры учёта и налогообложения, Государственное высшее учебное заведение «Киевский национальный экономический университет имени Вадима Гетьмана» (г. Киев, ул.. Дегтярёвская, 49/г)

E-mail: mar4ukuliana@gmail.com

ORCID: http://orcid.org/0000-0003-0971-1303

The article has been received 03.06.2019

Revision: 11.06.2019

Бібліографічний опис для цитування:

Hutsalenko L.V., Marchuk U.O. Financial statements according to the international financial reporting standards: requirements and realities of implementation. Економіка АПК. 2019. № 6. С. 36 - 44. 